Louisiana State University

LSU Digital Commons

Faculty Publications

Department of Biological Sciences

$1-1-2008$

\title{
Temperature and vegetation effects on soil organic carbon quality along a forested mean annual temperature gradient in North America
}

\author{
Cinzia Fissore \\ Michigan Technological University \\ Christian P. Giardina \\ USDA Forest Service Pacific Southwest Research Station \\ Randall K. Kolka \\ USDA Forest Service \\ Carl C. Trettin \\ USDA Forest Service \\ Gary M. King \\ Louisiana State University
}

See next page for additional authors

Follow this and additional works at: https://digitalcommons.Isu.edu/biosci_pubs

\section{Recommended Citation}

Fissore, C., Giardina, C., Kolka, R., Trettin, C., King, G., Jurgensen, M., Barton, C., \& Mcdowell, S. (2008).

Temperature and vegetation effects on soil organic carbon quality along a forested mean annual temperature gradient in North America. Global Change Biology, 14 (1), 193-205. https://doi.org/10.1111/ j.1365-2486.2007.01478.x

This Article is brought to you for free and open access by the Department of Biological Sciences at LSU Digital Commons. It has been accepted for inclusion in Faculty Publications by an authorized administrator of LSU Digital Commons. For more information, please contact ir@lsu.edu. 


\section{Authors}

Cinzia Fissore, Christian P. Giardina, Randall K. Kolka, Carl C. Trettin, Gary M. King, Martin F. Jurgensen, Christopher D. Barton, and S. Douglas Mcdowell 


\title{
Temperature and vegetation effects on soil organic carbon quality along a forested mean annual temperature gradient in North America
}

\author{
CINZIA FISSORE*, CHRISTIAN P. GIARDINA †, RANDALLK. KOLKA , CARL C. \\ TRETTIN§, GARY M. KING, MARTIN F. JURGENSEN*, CHRISTOPHER D. BARTON\| \\ and S. DOUGLAS MCDOWELL** \\ * Michigan Technological University, School of Forest Resources and Environmental Science 1400 Townsend Drive, Houghton, MI \\ 49931, USA, †USDA Forest Service, Pacific Southwest Research Station, Institute of Pacific Islands Forestry, 60 Nowelo Drive, \\ Hilo, HI 96720, USA, ‡USDA Forest Service, Northern Research Station, 1831 Highway 169 E., Grand Rapids, MN 55744, USA, \\ §USDA Forest Service, Southern Research Station, 2730 Savannah Highway, Charleston, SC 29414, USA, ๆDepartment of \\ Biological Sciences, Louisiana State University, Baton Rouge, LA 70803, USA, |Department of Forestry, University of Kentucky, \\ Newtown Pike, Lexington, KY 40546, USA, **Department of Geological Sciences, Michigan Technological University, 1400 \\ Townsend Drive, Houghton, MI 49931, USA
}

\begin{abstract}
Both climate and plant species are hypothesized to influence soil organic carbon (SOC) quality, but accurate prediction of how SOC process rates respond to global change will require an improved understanding of how SOC quality varies with mean annual temperature (MAT) and forest type. We investigated SOC quality in paired hardwood and pine stands growing in coarse textured soils located along a $22{ }^{\circ} \mathrm{C}$ gradient in MAT. To do this, we conducted 80-day incubation experiments at 10 and $30^{\circ} \mathrm{C}$ to quantify SOC decomposition rates, which we used to kinetically define SOC quality. We used these experiments to test the hypotheses that SOC quality decreases with MAT, and that SOC quality is higher under pine than hardwood tree species. We found that both SOC quantity and quality decreased with increasing MAT. During the $30^{\circ} \mathrm{C}$ incubation, temperature sensitivity $\left(Q_{10}\right)$ values were strongly and positively related to SOC decomposition rates, indicating that substrate supply can influence temperature responsiveness of SOC decomposition rates. For a limited number of dates, $Q_{10}$ was negatively related to MAT. Soil chemical properties could not explain observed patterns in soil quality. Soil pH and cation exchange capacity (CEC) both declined with increasing MAT, and soil C quality was positively related to $\mathrm{pH}$ but negatively related to CEC. Clay mineralogy of soils also could not explain patterns of SOC quality as complex (2:1), high CEC clay minerals occurred in cold climate soils while warm climate soils were dominated by simpler (1:1), low CEC clay minerals. While hardwood sites contained more SOC than pine sites, with differences declining with MAT, clay content was also higher in hardwood soils. In contrast, there was no difference in SOC quality between pine and hardwood soils. Overall, these findings indicate that SOC quantity and quality may both decrease in response to global warming, despite long-term changes in soil chemistry and mineralogy that favor decomposition.
\end{abstract}

Keywords: global warming, labile SOC, mean annual temperature, $Q_{10}$, stable SOC, temperate forests, tree species composition

Received 25 January 2007 and accepted 27 August 2007

\footnotetext{
Correspondence and present address: Cinzia Fissore, Department of Soil, Water, and Climate, University of Minnesota, 1991 Upper Buford Circle, St Paul, MN 55108, tel. + 612625 3125, fax + 612 625 2208, email: fisso001@umn.edu
}

Introduction

Soil organic carbon (SOC) quality depends on the capacity of soil microbes to utilize organic substrates

(C) 2007 The Authors 
(Ågren \& Bosatta, 1996) and on the availability of C compounds to decomposers (Rovira \& Vallejo, 2002). Changes in climate and vegetation type are expected to alter the quality and quantity of detrital inputs to soil and also the soil chemical and physical processes that regulate SOC quality. However, despite advances in our understanding of the specific mechanisms leading to SOC formation (Stevenson, 1994; Six et al., 2002), there is a surprisingly poor understanding of how SOC quality relates to climate and vegetation factors. This knowledge gap compromises our ability to predict the response of SOC storage to global change because positive effects of warming on SOC quality could result in a positive feedback on future warming, while warming-related reductions in SOC quality could result in the opposite negative feedback. Further, vegetation is anticipated to change in response to the direct and indirect effects of rising atmospheric $\mathrm{CO}_{2}$ and temperature (Bachelet et al., 2001; Walther et al., 2002). While it is well-established that species-related variation in plant tissue quality can alter decomposition rates of fresh detritus (Melillo et al., 1989; Berg \& Matzner, 1997), the relationship between initial quality of detrital inputs and SOC quality remains poorly understood (Scott \& Binkley, 1997; Giardina et al., 2001). Overall, few studies have evaluated how mean annual temperature (MAT) and vegetation type affect SOC quality.

It has been hypothesized that SOC can be formed along multiple pathways: (1) accumulation of ligninderived compounds; (2) accumulation of nitrogen-associated polyphenols derived from microbial utilization of both labile and recalcitrant compounds; and (3) physical protection of detrital $C$ from decomposition through bonding of $\mathrm{C}$ compounds onto the exchange sites of clay minerals and through stable aggregate formation (Stevenson, 1994; Jastrow \& Miller, 1997; Six et al., 2002). Chemical protection of SOC occurs because only specialized microbial groups have developed enzymes capable of attacking lignin, lignin-like compounds or compounds formed through the condensation and/or polymerization of polyphenol-derived quinones (Srebotnik et al., 1994; Stevenson, 1994; Waldrop \& Firestone, 2004). Physical protection of SOC in clay- and silt-dominated aggregates occurs because enzymes do not have access to protected SOC (Balesdent et al., 1990; Six et al., 2001). As a result, SOC is only slowly decomposed relative to fresh litter (Trumbore, 1997; Gaudinski et al., 2000; Giardina \& Ryan, 2000; Paul et al., 2001).

A critical but rarely examined question in global change science is the extent to which climate regulates SOC quality. The potential mechanisms driving the influence of MAT on SOC quality include increased litter production (Giardina et al., 2005; Raich et al.,
2006), accelerated litter decomposition (Meentenmeyer, 1982), accelerated stabilization of the products of decomposition (Dalias et al., 2001; Thornley \& Cannell, 2001), and in the long-term weathering losses of clay minerals with a high affinity for C (Birkeland, 1999).

Two contrasting hypotheses have emerged for the net effect of these temperature-dependent processes on SOC quality, with implications for whether soils will feedback positively or negatively on future warming. Shang \& Tiessen (2000) proposed that SOC formed at high MAT is less stable than SOC formed at low MAT, such that a positive slope would characterize the relationship between SOC decomposition rates and MAT. Alternatively, aboveground net primary production (NPP) and belowground C allocation both increase with MAT across biome types (Gower et al., 1994; Shaver et al., 2000; Giardina et al., 2005), such that soils at warm sites receive greater inputs of both labile (e.g. sugars) and decay resistant (e.g. lignin) compounds. Despite higher inputs, however, total SOC concentrations within taxonomic soil orders appears to be relatively constant across MAT (Sanchez, 1976). Therefore, we hypothesize that larger above and belowground litter inputs combined with higher litter decomposition rates should result in reduced quality of detrital inputs to mineral soils. When coupled with higher stabilization rates at warmer sites (Dalias et al., 2001; Thornley \& Cannell, 2001), lower quality inputs should reduce SOC quality at warm sites (Fig. 1).

Vegetation also can influence SOC quality by altering the relative abundance of labile and recalcitrant $C$ compounds returned to soil (Berg, 1986; Melillo et al., 1989; Guo \& Gifford, 2002). Although clear differences in litter chemical composition exist across plant taxa (e.g. broadleaf deciduous and evergreen conifer), the effect of vegetation type on SOC quality, particularly in relation to temperature, remains unclear (Smolander et al., 2005). The 'decay filter' hypothesis postulates that initial differences in detritus quality disappear soon after initiation of the decomposition process, and so initial differences should have little influence on SOC quality (Melillo et al., 1989). Alternatively, initial differences in litter quality may relate inversely to SOC quality because of enhanced microbial processing of higher quality and higher nitrogen $(\mathrm{N})$ content litter, increased production of decay resistant compounds, and/or variation in microbial species composition (Giardina et al., 2001; Joffre \& Ågren, 2001; Russell et al., 2007). Rapid utilization of labile polymers characterizing high-quality litter has been observed to diminish with time, leaving behind microbially derived stable compounds and residual detritus that are more recalcitrant than the residual detritus of initially lower quality litter (Prescott et al., 2000). Possible causal 


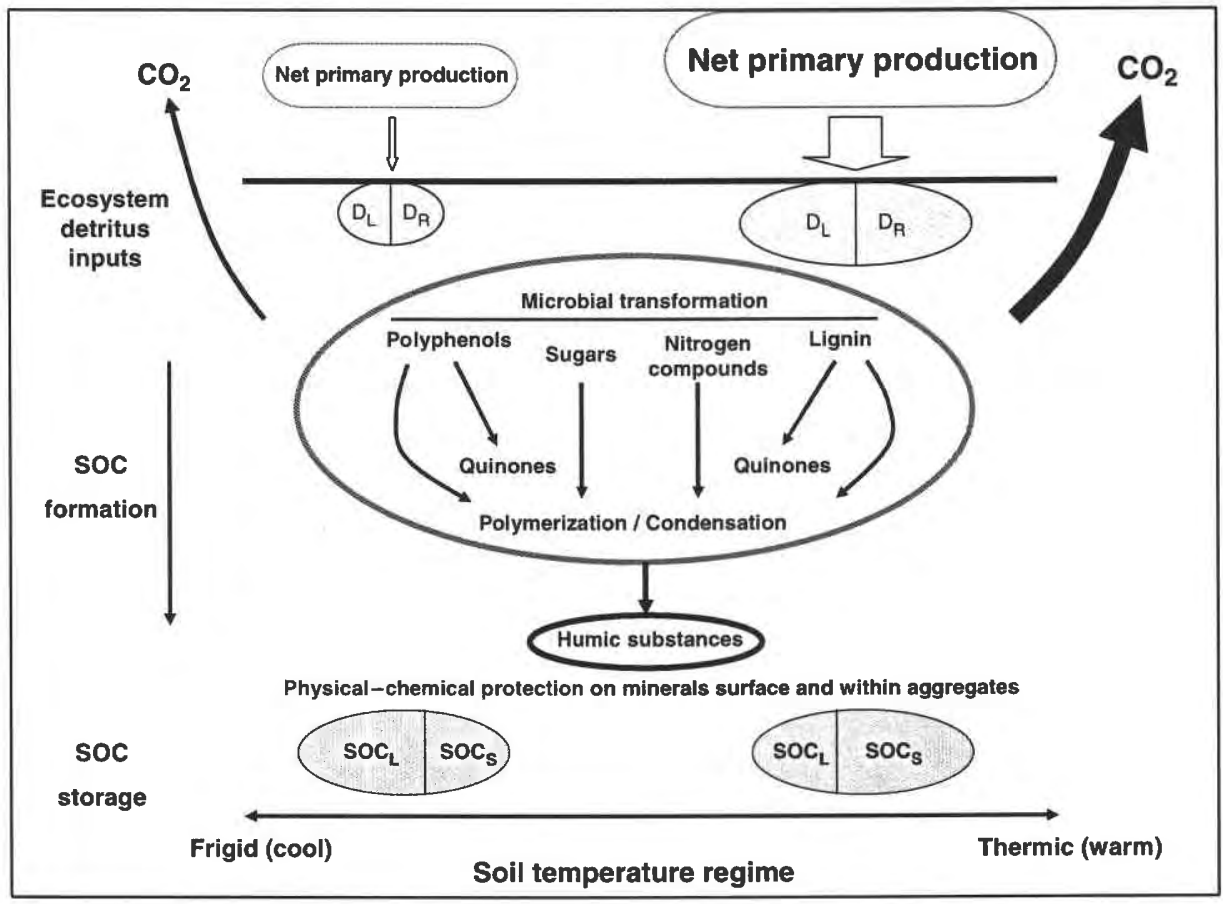

Fig. 1 Representation of how temperature and carbon inputs are hypothesized to affect soil organic carbon (SOC) quality along a mean annual temperature (MAT) gradient. Carbon inputs to soil are characterized by similar proportions of readily decomposable $\left(\mathrm{D}_{\mathrm{L}}\right)$ and decay-resistant $\left(\mathrm{D}_{\mathrm{R}}\right)$ compounds, while total ecosystem detritus inputs increase with temperature. The amount of $\mathrm{CO}_{2}$ released through respiration is higher at high temperature due to increased microbial activity. Formation of SOC depends on the rate at which microbial degradation takes place. Different utilization pathways depend on initial C substrate quality, which help to determine SOC quality. The resulting SOC quality, described as the relative amount of labile $\left(\mathrm{SOC}_{\mathrm{L}}\right)$ and stable $\left(\mathrm{SOC}_{\mathrm{S}}\right)$ compounds derives from the combined effects of temperature and substrate quality on microbial activity. At low MAT, lower amounts of $\mathrm{D}_{\mathrm{L}}$ and $\mathrm{D}_{\mathrm{R}}$ undergo decomposition and microbial activity is lower. In contrast, at high MAT microbial activity is enhanced and $D_{L}$ compounds are rapidly utilized. Consequently, soils store higher amounts of $\mathrm{SOC}_{\mathrm{L}}$ at low MAT than at high temperature, and conversely, at high MAT, soils store more $\mathrm{SOC}_{\mathrm{S}}$, and so SOC quality decreases with increasing MAT.

relationships between recalcitrant substrates, microbial activity and climate may relate to the $\mathrm{N}$ content of the substrate (Berg \& Meentemeyer, 2002). However, we are aware of no study that has examined the response of SOC quality to vegetation type along a gradient in MAT.

The purpose of this study was to investigate how SOC quality varies in relation to MAT and the extent to which this relationship with MAT is modified by forest type. The extended range of MAT at which forests occur in North America and the occurrence of hardwood and monospecific pine stands across this range provide a unique opportunity to investigate how temperature and forest type influence SOC quality. In this study, we developed a $22^{\circ} \mathrm{C}$ gradient in MAT that had the following characteristics: (i) relatively uniform coarsetextured soil; (ii) paired hardwood and pine sites at each MAT sampling point along the gradient; and (iii) relatively constant growing season soil water balance because both mean annual precipitation (MAP) and MAT were linearly and positively related.
We relied on 80-day laboratory incubations to quantify SOC quality. In this widely used method, SOC quality is kinetically defined through measurements of $\mathrm{CO}_{2}$ release from incubated soils (Paul \& Clark, 1996; Townsend et al., 1997; Paul et al., 2001, 2006). Lab incubation experiments provide insights about microbial utilization of SOC and hence SOC quality without the confounding influences of root respiration and climatic variation that are encountered in the field (Collins et al., 2000). To examine the effects of incubation temperature on $\mathrm{SOC}$ quality, we quantified $\mathrm{CO}_{2}$ release from soils incubated at both high $\left(30^{\circ} \mathrm{C}\right)$ and low $\left(10^{\circ} \mathrm{C}\right)$ laboratory incubation temperatures (LIT).

We hypothesized that SOC quality decreases with increasing MAT because the quantity of detrital inputs and microbial decomposition of those inputs both increase with MAT. As a result, a smaller, lower quality fraction of a larger amount of detritus enters soils at warm sites. Further, greater SOC stabilization at higher MAT (greater $\mathrm{N}$ availability, warmer temperatures, and 
accelerated stabilization reaction rates) may further promote the accumulation of low-quality SOC at warm sites. In addition, we hypothesized that SOC quality would be lower under hardwoods than pine because the high-quality, high-N detritus from hardwoods results in high microbial use efficiency, enhances C stabilization, and suppresses the production of lignin degrading enzymes. Finally, because soil chemical properties can exert a strong influence on SOC content and turnover (Torn et al., 1997), we examined soil clay mineralogy, $\mathrm{pH}$ and CEC across our gradient and related their variation to SOC content and decomposition.

\section{Methods}

\section{Site description}

For our soil incubation experiments, we sampled soils from 26 closed-canopy hardwood- and pine-dominated stands located along a $22^{\circ} \mathrm{C}$ gradient in MAT (Table 1). Each stand was considered mature for the region, with age varying inversely with MAT. Most sites were located within USDA National Forest Experimental Forests or University Experimental Forests with known management histories. Exceptions include the two pine sites and one hardwood site in Michigan, which are located on land that had been owned and managed by MeadWestvaco Inc., again with a known record of management. Climate data were available for nearly all sites, and where data were not available, climate data for nearby $(<70 \mathrm{~km})$ sites were used.

Each point on our MAT gradient included paired pine-dominated stands and maple-dominated (Minnesota and warmer) or aspen-dominated (Michigan and cooler) hardwood stands (Table 1). At the southern sites, aspen does not occur and hence only pine-dominated and maple-dominated stands were sampled. Overstory maple species do not occur at the Colorado site, so only soils from pine-dominated and aspendominated sites were sampled. For Michigan and Minnesota sites, both aspen and maple stands were sampled. With the exception of Colorado, hardwood sites were represented by uneven-aged stands of red maple (Acer rubra) and sugar maple (Acer saccharum) in association with other hardwoods including oak (Quercus spp.) at all sites and hickory (Corya spp.) for the southern sites. For Michigan and the cooler sites, hardwood sites also included even-aged aspen stands. Composition of the even-aged pine stands varied along our MAT gradient, and included Pinus contorta (Colorado), $P$. resinosa (Minnesota and Michigan), P. virginiana (Kentucky) and P. taeda (South Carolina and Georgia). Within a region, we attempted to hold slope, aspect and eleva- tion constant. For Colorado we chose sites that were approximately $3000 \mathrm{~m}$ a.s.l., south-east in aspect and with $<10 \%$ slope. For other sites on the gradient, we chose sites that were level and had no aspect. Across the gradient, MAP varied from $474 \mathrm{~mm} \mathrm{yr}^{-1}$ in Colorado to $1332 \mathrm{~mm} \mathrm{yr}^{-1}$ in South Carolina. Notably, while MAP is higher at warmer sites, evaporation and transpiration losses are greater at the warmer sites. As a result, calculated growing season water balance is relatively constant across the gradient.

\section{Soil sampling}

Soil sampling was conducted by depth with no separation into soil horizons. Specifically, soil samples were collected from the top $20 \mathrm{~cm}$ of the mineral soil by inserting a $10 \mathrm{~cm}$ diameter soil auger into the soil after carefully removing organic horizon material (forest floor). Soils were shipped in a cooler to the USDA Forest Service Forestry Lab in Houghton, MI, immediately after sampling ( $<2$ days). Soils were sieved fresh through a $2-\mathrm{mm}$ sieve to remove roots and rocks. All sieved soils were then dried to constant moisture at $30^{\circ} \mathrm{C}$ in a forced air oven for analysis and storage.

\section{Soil chemical-physical characterization}

Water holding capacity (WHC) of air-dried samples was measured by saturation of a known amount of dry soil $(0 \% \mathrm{WHC})$ placed in a funnel with filter. A known mass of soil was used to fill the funnel to a known volume to reach a target bulk density of $1 \mathrm{Mg} \mathrm{m}^{-3}$. Water was added to soil until saturation, and soil weight after all free water had drained (ca. $6 \mathrm{~h}$ ) represented $100 \%$ WHC. Soil $\mathrm{pH}$ was measured with a $\mathrm{pH}$ meter using $20 \mathrm{~g}$ of soil mixed in $20 \mathrm{~mL}$ of $\mathrm{H}_{2} \mathrm{O}$ and $200 \mu \mathrm{L}$ of $1 \mathrm{M} \mathrm{CaCl}_{2}$ solution. Cation exchange capacity (CEC) was calculated as the sum of charge equivalents of exchangeable ions. Total $\mathrm{C}$ and $\mathrm{N}$ estimates for air-dry soils were obtained using an Elemental Combustion System 4010 Mass Spectrometer (Costech, Valencia, CA, USA).

Soil texture was calculated using the hydrometer procedure, by which the relative proportion of sand and clay are determined gravimetrically according to the settling time of soil suspension, while the proportion of silt is obtained by difference (Carter, 1993). Clay mineral composition was determined by isolating the clay fraction through sedimentation in a column after dispersion in $10 \mathrm{~mL}$ of $3 \%$ sodium hexametaphosphate followed by flocculation in $2 \mathrm{~N} \mathrm{MgCl}_{2}$ and repeated washing with deionized water (Gee \& Bauder, 1986). Subsequently, oriented clay samples were obtained by adding the separated material to glass slides using an eye-dropper and then air-drying. Mineralogy was 
Table 1 Site location and soil characteristics of the pine and hardwood stands sampled along the $22^{\circ} \mathrm{C}$ mean annual temperature (MAT) gradient

\begin{tabular}{|c|c|c|c|c|c|c|c|c|c|c|}
\hline Sample & Location & MAT ${ }^{\circ} \mathrm{C}$ & MAP mm yr ${ }^{-1}$ & Forest type & Main species & Clay \% & $\mathrm{pH}$ & CEC meq $100 \mathrm{~g}^{-1}$ soil & $\mathrm{C} \%$ & $\mathrm{~N} \%$ \\
\hline CO-P1 & Colorado & -2 & 474 & Pine & P. contorta & 8.3 & 5.8 & 6.8 & 2.20 & 0.09 \\
\hline CO-P2 & Colorado & -2 & 474 & Pine & $P$. contorta & 12.0 & 5.6 & 10.5 & 2.64 & 0.10 \\
\hline CO-A1 & Colorado & -2 & 474 & Hardwood & P. tremuloides & 10.0 & 6.1 & 26.4 & 8.07 & 0.53 \\
\hline $\mathrm{CO}-\mathrm{A} 2$ & Colorado & -2 & 474 & Hardwood & P. tremuloides & 7.0 & 6.1 & 10.6 & 3.48 & 0.11 \\
\hline MN-P1 & Minnesota & 4 & 700 & Pine & P. resinosa & 4.5 & 5.6 & 4.5 & 1.45 & 0.07 \\
\hline MN-P2 & Minnesota & 4 & 700 & Pine & P. resinosa & 3.0 & 5.3 & 3.2 & 1.05 & 0.05 \\
\hline MN-A1 & Minnesota & 4 & 700 & Hardwood & P. tremuloides & 8.5 & 5.7 & 4.8 & 1.60 & 0.09 \\
\hline MN-H1 & Minnesota & 4 & 700 & Hardwood & Acer spp. & 8.0 & 5.8 & 6.9 & 1.93 & 0.11 \\
\hline MI-P1 & Michigan & 5 & 771 & Pine & P. resinosa & 1.0 & 4.9 & 1.7 & 1.07 & 0.05 \\
\hline MI-P2 & Michigan & 5 & 867 & Pine & P. resinosa & 2.0 & 4.7 & 1.6 & 1.33 & 0.07 \\
\hline MI-A1 & Michigan & 5 & 771 & Hardwood & P. tremuloides & 3.0 & 5.0 & 2.0 & 1.34 & 0.07 \\
\hline MI-H1 & Michigan & 5 & 771 & Hardwood & Acer spp. & 4.0 & 4.9 & 5.5 & 3.38 & 0.24 \\
\hline MI-H2 & Michigan & 5 & 867 & Hardwood & Acer spp. & 2.0 & 4.8 & 2.2 & 1.62 & 0.09 \\
\hline KY-P1 & Kentucky & 12 & 850 & Pine & $P$ virginiana & 10.0 & 4.4 & 3.2 & 2.24 & 0.06 \\
\hline KY-H1 & Kentucky & 12 & 850 & Hardwood & Acer spp. & 16.0 & 5.7 & 6.6 & 2.10 & 0.16 \\
\hline $\mathrm{KY}-\mathrm{H} 2$ & Kentucky & 12 & 850 & Hardwood & Acer spp. & 15.0 & 4.8 & 3.7 & 2.34 & 0.14 \\
\hline KY-H3 & Kentucky & 12 & 850 & Hardwood & Acer spp. & 8.0 & 4.6 & 2.1 & 1.22 & 0.05 \\
\hline SC-P1 & South Carolina & 18 & 1332 & Pine & P. virginiana & 4.0 & 4.8 & 2.1 & 1.74 & 0.06 \\
\hline SC-P2 & South Carolina & 18 & 1332 & Pine & P. virginiana & 3.5 & 4.9 & 1.3 & 0.88 & 0.03 \\
\hline SC-P3 & South Carolina & 18 & 1332 & Pine & P. virginiana & 1.0 & 4.7 & 1.4 & 1.37 & 0.04 \\
\hline SC-H1 & South Carolina & 18 & 1332 & Hardwood & Acer spp. & 20 & 4.4 & 5.8 & 2.06 & 0.09 \\
\hline SC-H2 & South Carolina & 18 & 1332 & Hardwood & Acer spp. & 16 & 4.3 & 3.5 & 1.76 & 0.07 \\
\hline $\mathrm{SC}-\mathrm{H} 3$ & South Carolina & 18 & 1332 & Hardwood & Acer spp. & 13 & 4.6 & 2.8 & 1.47 & 0.06 \\
\hline SC-H4 & South Carolina & 18 & 1332 & Hardwood & Acer spp. & 3.0 & 4.8 & 1.9 & 1.24 & 0.05 \\
\hline GA-P1 & Georgia & 20 & 1270 & Pine & P. taeda & 3.5 & 4.5 & 1.3 & 1.00 & 0.04 \\
\hline GA-H1 & Georgia & 20 & 1270 & Hardwood & Acer spp. & 13 & 5.2 & 3.6 & 2.50 & 0.17 \\
\hline
\end{tabular}

With the exception of Colorado, hardwood stands were all uneven-aged red and sugar maple in association with other hardwoods, including oak at all sites and hickory for the southern sites. Where aspen instead of maple was sampled, it was from even-aged stands. For Colorado, samples were taken from Fraser Experimental Forest and Routt National Forest (USDA Forest Service); in Minnesota from Marcel and Cutfoot Experimental Forests (USDA Forest Service), in Michigan from industrial lands and from Michigan Technological University's Alberta Forestry Center; in Kentucky from the Daniel Boone National Forest (USDA Forest Service) and the University of Kentucky Robinson Forest; in South Carolina from Santee Experimental Forest and Francis Marion National Forests (USDA Forest Service); and in Georgia from the University of Georgia Agricultural Experiment Station.

MAP, Mean annual precipitation.

analyzed on a Scintag diffractometer (Scintag Inc., Cupertino, CA, USA) with a range of 2-36 $2 \theta$, at a scan rate of $2^{\circ} \mathrm{min}^{-1}$. Subsequent diffractions of the same samples were conducted after exposure to a vapor of ethylene glycol overnight in oven at $65^{\circ} \mathrm{C}$ and heating in a furnace at 120,350 , and $550^{\circ} \mathrm{C}$ for $2 \mathrm{~h}$. These different treatments allow discrimination among minerals according to the expandable properties of their structures (Moore \& Reynolds, 1989). Glycolation causes expansion of highly expandable smectite, with the characteristic peak shifting from $14 \AA$ to ca. $17 \AA$, while low-expandable smectite does not present such swelling. Further, the extent to which the peak at $14 \AA$ collapses toward $10 \AA$ and the temperature required for the collapse are indicative of the degree of hydroxyl-Al interlayer filling, with low-expandable smectite being characterized by incomplete collapse toward $10 \AA$ because of the strong electrostatic forces pulling the structural layers together. Distinction between chlorite and kaolinite is obtained by the collapse of the kaolinite peaks after heating at $550^{\circ} \mathrm{C}$, while the distinctive peak of illite is constant at $10 \AA$ across treatments.

Accurate quantification of soil clay minerals is still not possible with current methods (Kahle et al., 2002) because of both intrinsic complexity of the soil mineral phase and because of the numerous assumptions involved in interpreting $X$-ray diffraction spectra. Lack of standard procedures for conducting these analyses also complicates attempts to quantify mineralogy from these spectra (Ottner et al., 2000; Kahle et al., 2002). For this reason, we present semiquantitative estimates of the relative abundance of the major clay minerals derived

(C) 2007 The Authors

Journal compilation (C) 2007 Blackwell Publishing Ltd, Global Change Biology, 14, 193-205 
from software-based (Scintag Inc.) estimates of peak area of X-ray diffraction spectra following subtraction of spectra baseline (Thorez, 1976).

\section{SOC decomposition rates}

Thirty grams of soil from each of 26 forest stands located along the MAT gradient were placed in $120 \mathrm{~mL}$ specimen cups, hydrated, and placed into $1 \mathrm{~L}$ mason jars for incubation. Lids with rubber septa for gas sampling were used to seal the jars during $24 \mathrm{~h}$ measurement periods that included sampling for initial and final $\mathrm{CO}_{2}$ concentrations. One set of soils was incubated at $10^{\circ} \mathrm{C}$, representing average MAT across our gradient, while an identical second set was incubated at $30^{\circ} \mathrm{C}$, representing a temperature typically used in incubation studies (Paul et al., 2001). Throughout the experiment, all soils were maintained at constant temperature $\left(10 \pm 1\right.$ or $30 \pm 1^{\circ} \mathrm{C}$ ) by conducting incubations in Precision 815 low-temperature incubators (Winchester, VA, USA). We maintained soils at constant moisture $(60 \pm 5 \% \mathrm{WHC})$ that in a pre-experiment trial was determined to be near optimal for microbial decomposition (maximum $\mathrm{CO}_{2}$ evolution rates). Moisture levels were maintained by regularly checking soil weight and adjusting with tap water. Open containers of water were placed in the incubators to increase relative humidity and minimize water loss from soil.

We quantified $\mathrm{CO}_{2}$ efflux $\left(\mathrm{gC}^{-1}\right.$ soil day $\left.{ }^{-1}\right)$ from incubated soils using an Agilent 6890 Gas Chromatograph (Agilent Inc., Palo Alto, CA, USA). Pre-experiment trials were conducted to establish analytical reproducibility and the replications required to achieve accurate means. Before sampling, jars were removed from incubators, equilibrated with ambient air under a fume hood, sealed for baseline $\mathrm{CO}_{2}$ sampling, and immediately returned to 10 or $30^{\circ} \mathrm{C}$ LIT for $24 \mathrm{~h}$ before resampling for head space $\mathrm{CO}_{2}$ concentrations. The baseline $\mathrm{CO}_{2}$ concentration at time zero, used for calculating $\mathrm{CO}_{2}$ efflux during the measurement period, was recorded at each sampling event from a subset of 5-10 jars immediately after closing the jars. Head space sampling involved collection of $50 \mathrm{~mL}$ of headspace gas from each jar with a gas-tight syringe. All gas samples were analyzed within $8 \mathrm{~h}$ from collection, which occurred at 1, 3, 10, 22, 42, and 80 days. SOC decomposition rates were calculated from gas chromatograph $\mathrm{CO}_{2}$ efflux results and are expressed as $\mathrm{mgCg}^{-1}$ soil $\mathrm{Cday}^{-1}$. The $\%$ SOC lost over the entire incubation was calculated as the sum of all $\mathrm{C}$ lost over the entire 80-day incubation and was expressed as gClost g $^{-1}$ soil C $\times 100$.

\section{Statistical analysis}

The area of study was divided into six MAT zones, ranging from an MAT $=-2$ to $20^{\circ} \mathrm{C}$. Within each MAT zone, we sampled between two and six replicate stands of forest. For each of these replicate stands, we collected three subsamples that were combined into a single soil sample for that replicate stand. Because stands were geographically separated by other forest types, soil types, land-uses (up to $70 \mathrm{~km}$ apart within an MAT zone), we treated the stand as a true replicate $(n=26)$. Within each MAT zone, we sampled both pine and hardwood (maple dominated, aspen dominated, or both), and so were able to add a second qualitative variable to our regression analyses. Specifically, we used simple and multiple linear regression and paired $t$-tests to examine the effects of MAT, soil texture, soil chemical measures and forest type on $\mathrm{CO}_{2}$ efflux, SOC content, SOC decomposition rate, and \% SOC loss. In all cases, an $\alpha$ of 0.05 was used to determine significance. We did not consider the site $\mathrm{CO}-\mathrm{A} 1$ as an outlier despite $\% \mathrm{C}$ values that were three times higher than the mean. Typically, soil $\mathrm{C}$ concentrations are highly variable, and so these values are not surprising. Alternatively, at the time of sampling, part of the $O$ horizon may have been accidentally included into the sample due to the difficulties in distinguishing the transition between $\mathrm{Oa}$ and A soil horizons. Reanalysis of SOC content and SOC decomposition rates revealed no measurement errors.

\section{Results}

\section{Soil chemical-physical characteristics}

Soil $\mathrm{pH}$ declined significantly with MAT (Fig. 2a) from a high of about 6.1 at an MAT of $-2{ }^{\circ} \mathrm{C}$ to a low of 4.3 at an MAT of $20^{\circ} \mathrm{C}\left(R^{2}=0.53 ; P<0.01 ; n=26\right)$. There were no significant effects of forest type on soil pH $(4.90 \pm 0.10$ for pine and $5.10 \pm 0.10$ for hardwood stands; mean \pm 1 SE). Soil CEC also was negatively related to MAT (Fig. $2 \mathrm{~b}$ ), and CEC was higher in hardwood than pine stands. Soil clay content varied between $1 \%$ and $20 \%$ (mean $=8.00 \% ; \mathrm{SE}=1.10 ; n=26$ ), but in contrast to $\mathrm{pH}$ and CEC, soil clay content was unrelated to MAT $\left(R^{2}=0.04 ; P=0.36\right)$ with variation within a region often equal to variation across regions (Fig. 2c). Overall, soil clay content was higher in soils under hardwood stands compared with pine stands (Fig. 2c).

Across sites, clay minerals in soil were composed mainly of illite, chlorite, kaolinite, and high- or low-charge smectite (Fig. 3), though relative abundances of these clay minerals varied with MAT. Expandable, typically high CEC clay minerals were 


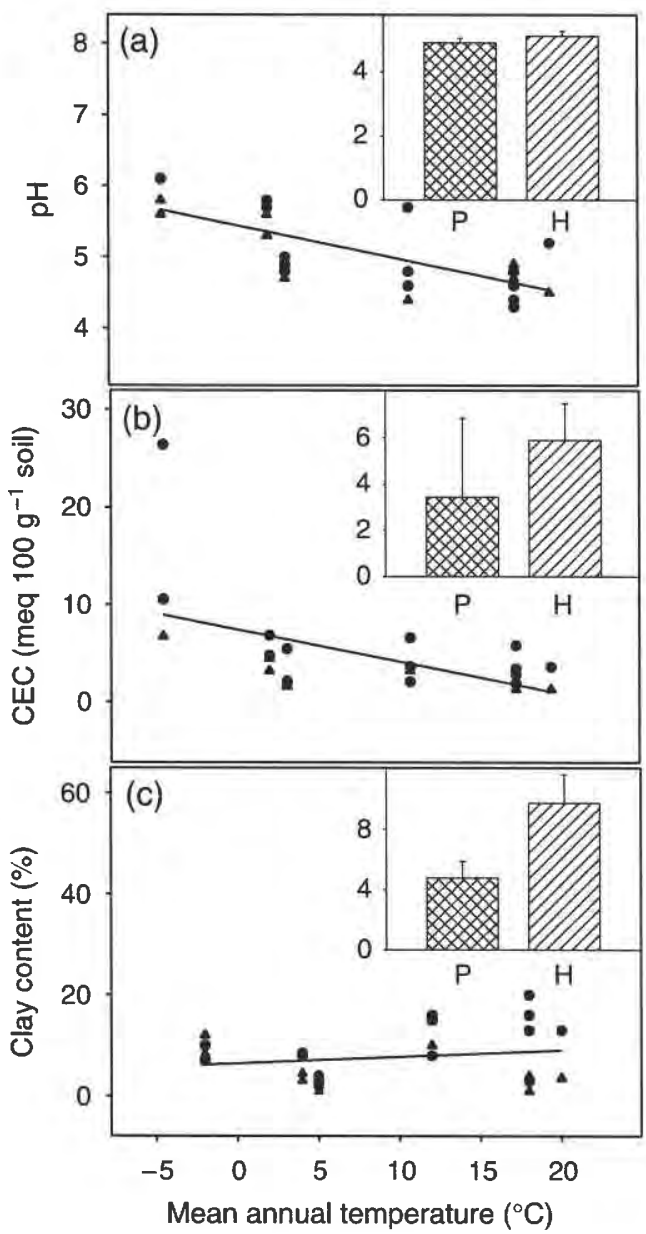

Fig. 2 Relationship between mean annual temperature (MAT) and main soil chemical-physical characteristics along the MAT gradient with $(\bullet)$ for hardwood stands and $(\boldsymbol{\Lambda})$ for pine stands. (a) soil $\mathrm{pH}=5.56-0.05 \times(\mathrm{MAT}), R^{2}=0.53, P<0.01, n=26$; (b) soil cation exchange capacity $(\mathrm{CEC})=8.25-0.36 \times(\mathrm{MAT}), R^{2}=$ $0.30, P<0.05, n=26$; (c) soil clay content (not significant). Bar graphs represent the soil characteristics (mean $+\mathrm{SE}$ ) according to the forest type.

more abundant at the cold end of the gradient and decreased with increasing MAT. In contrast, kaolinite and low CEC minerals were more abundant in soils from Kentucky, South Carolina, and Georgia. We observed only trace amounts of chlorite in these warm climate soils.

In line with mineralogy, $\mathrm{pH}$ and $\mathrm{CEC}$ data, SOC content was negatively albeit weakly related to MAT (Fig. 4). Across forest types, SOC content was not significantly related to clay content $\left(R^{2}=0.08\right.$; $P=0.18 ; n=26$ ). Across the gradient, hardwood stands $(n=15)$ stored significantly more SOC than pine ( $n=11)$ stands $(2.40 \pm 0.44 \%$ and $1.54 \pm 0.18 \%$, respectively; Fig. 4).

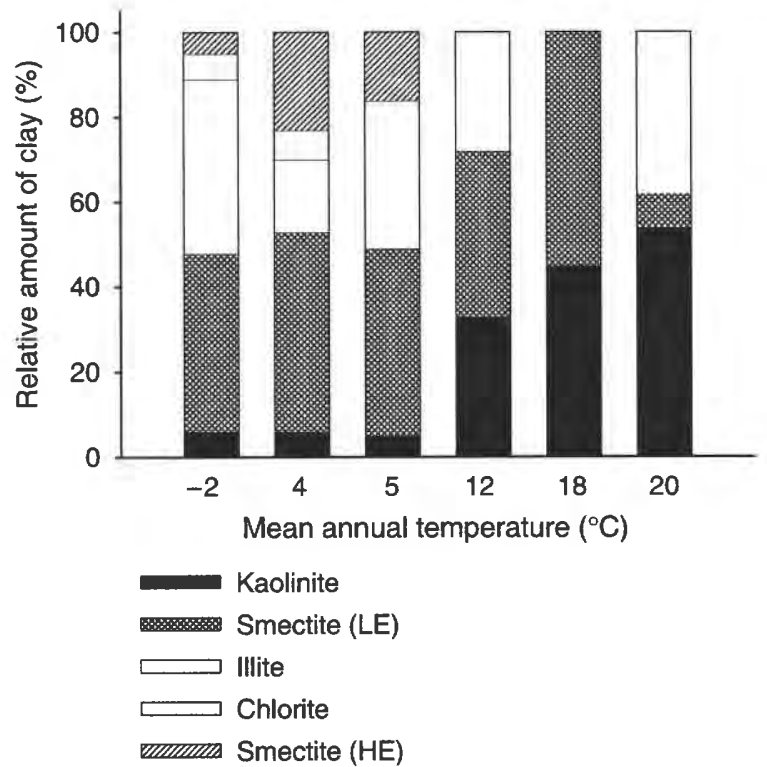

Fig. 3 Relative distribution of the main clay mineral groups along the mean annual temperature gradient. Percent values are based on semiquantitative analysis estimated from peak areas of the basal reflections. $\mathrm{HE}=$ highly expandable smectite, $\mathrm{LE}=$ low-expandable smectite. Differences in charge per formula unit $<0.6$ and $>0.6$ identifies high and low expandable smectite, respectively (Douglas, 1989; Barnhisel \& Bertsch, 1989; McBride, 1994).

\section{SOC decomposition rates}

We observed high reproducibility of soil $\mathrm{CO}_{2}$ efflux measurements during the incubation experiment. Efflux rates observed in a trial experiment conducted under identical conditions 30 days before the initiation of the current experiment were highly correlated with rates observed in the main experiment $\left(R^{2}=0.96\right.$; $P<0.01 ; n=26$ ). To examine linearity, we separately incubated 10 subsamples of a single soil and found that variation in efflux rates across soil subsamples was very low and the linear increase in headspace $\mathrm{CO}_{2}$ concentration over 24 -h trials was very high $\left(R^{2}=0.99\right.$; $P<0.01 ; n=10$ ).

Values for SOC decomposition rates of 1.98 and $0.38 \mathrm{mg} \mathrm{Cg}^{-1}$ soil Cday ${ }^{-1}$ were observed at day 1 of the incubation at high and low LIT, respectively. At high LIT, rates of SOC decomposition $\left(\mathrm{mgC}^{-1}\right.$ soil Cday $\left.{ }^{-1}\right)$ declined sharply in the first 3 weeks of incubation. A more muted pattern was observed for low-LIT soils (Fig. 5). Subsequently, SOC decomposition rates stabilized for both high and low LIT. At high LIT, SOC decomposition rates decreased from an average of $1.56 \mathrm{mg} \mathrm{Cg}^{-1}$ soil Cday ${ }^{-1}$ in the first 10 days of incubation to $0.43 \mathrm{mg} \mathrm{Cg}^{-1}$ soil Cday $^{-1}$ in the second half of the incubation. At low LIT, values varied from 0.49 to $0.21 \mathrm{mgC} \mathrm{g}^{-1}$ soil C day ${ }^{-1}$. 


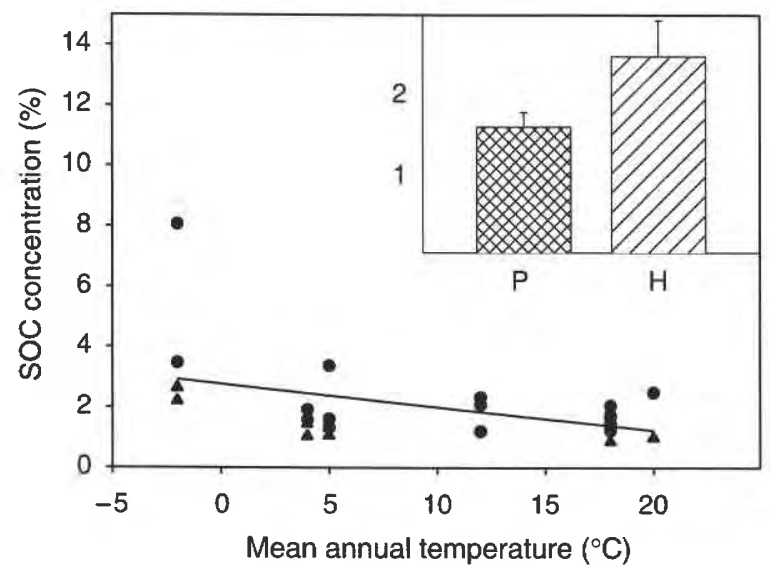

Fig. 4 Relationship between soil organic carbon (SOC) content and mean annual temperature (MAT) along the MAT gradient, with ( $\bullet$ ) for hardwood stands and ( $\Delta$ ) for pine stands. SOC $(\%)=2.77-0.08 \times(\mathrm{MAT}), R^{2}=0.18, P<0.01, n=26$. Bar graph represents the distribution of SOC (mean $+\mathrm{SE}$ ) between forest types.

\section{SOC quality along the MAT gradient}

Across sites and dates, SOC decomposition rates were negatively related to MAT. The regression slopes describing the relationship between SOC decomposition rate and MAT were negative for each sampling event in our 80-day incubation experiment. By the end of the experiment, \%SOC loss was greater for cold climate than warm climate soils, with \%SOC loss decreasing linearly with increasing MAT (Fig. 6).

The $Q_{10}$ of SOC decomposition rate response to LIT (calculated here as $\left[R_{1} / R_{2}\right]^{\wedge} 10 /\left[\mathrm{LIT}_{1}-\mathrm{LIT}_{2}\right]$, where $R_{1}$ and $R_{2}$ equal SOC decomposition rates at $\mathrm{LIT}_{1}$ and $\mathrm{LIT}_{2}$ ) ranged from an initial mean value of $2.00 \pm 0.10$ to a mean value of $1.50 \pm 0.10$ at the end of the incubation (Fig. 5). At high LIT, $Q_{10}$ values were strongly related to SOC decomposition rates over the 80 -day incubation $\left(Q_{10}=0.40 \times\right.$ SOC dec. rates +1.34 ; $R^{2}=0.44 ; P<0.01 ; n=150$ ). No significant relationship was found between $Q_{10}$ and SOC decomposition rates at low LIT $\left(Q_{10}=-0.30 \times \mathrm{SOC}\right.$ dec. rates +1.77 ; $R^{2}=0.10 ; P=0.90 ; n=150$ ). We observed a strong negative relationship between $Q_{10}$ and MAT on days 10 $\left(R^{2}=0.68 ; P<0.01\right)$ and $22\left(R^{2}=0.29 ; P<0.01\right)$ of the incubation.

\section{SOC decomposition rates and forest type}

Across sites, \% SOC loss after 80 day of incubation at high LIT was similar for hardwoods and pine stands

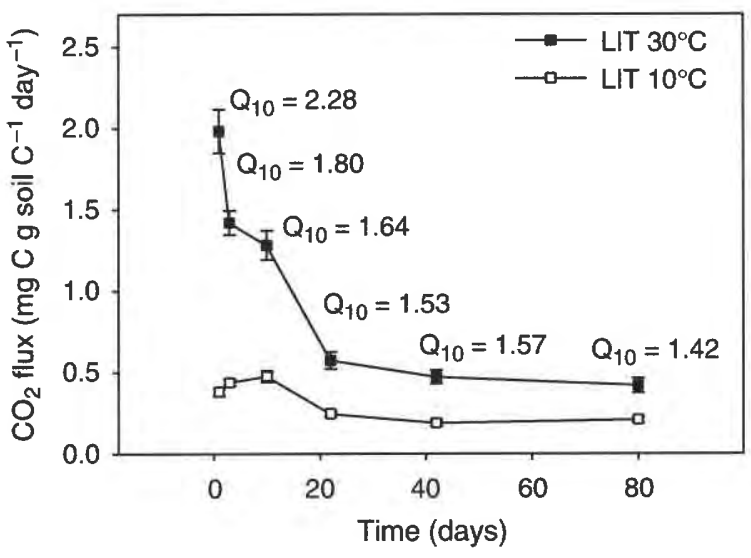

Fig. 5 Soil organic carbon decomposition rates (mgCgsoil $\mathrm{C}^{-1}$ day $^{-1}$ ) during 80 days of incubation for soils sampled along a $22^{\circ} \mathrm{C}$ mean annual temperature (MAT) gradient in North America. Each data point represents the mean $( \pm \mathrm{SE})$ of the temperature response of all samples $(n=26)$. LIT, laboratory incubation temperature

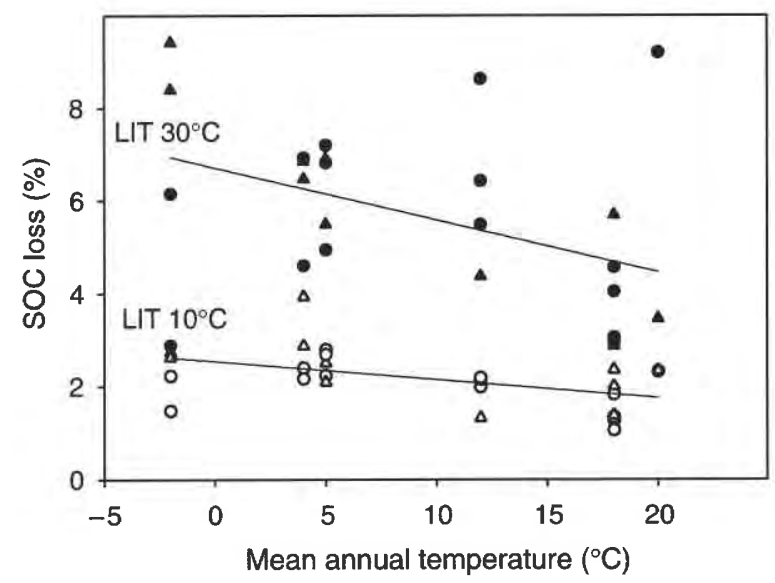

Fig. 6 Laboratory incubation temperature (LIT) effects on soil carbon losses from pine and hardwood stands along the mean annual temperature (MAT) gradient, with $(\bullet)$ for hardwood stands and ( $\Delta$ ) for pine stands. At LIT $30^{\circ} \mathrm{C}$, SOC loss $\%=6.72-0.11 \times(\mathrm{MAT}), R^{2}=0.19, P=0.03, n=26$; at LIT $10^{\circ} \mathrm{C}$, SOC loss $(\%)=2.54-0.04 \times(\mathrm{MAT}), R^{2}=0.24, P=0.01, n=26$.

( $5.60 \pm 0.51 \%$ and $5.70 \pm 0.65 \%$, respectively). At low LIT, \%SOC loss was slightly lower for hardwood than for pine stands $(2.00 \pm 0.13 \%$ and $2.38 \pm 0.22)$. At low and high LIT, \%SOC loss was inversely related to MAT in both hardwood and pine stands (Fig. 6), as described by the following equations:

(C) 2007 The Authors Journal compilation (C) 2007 Blackwell Publishing Ltd, Global Change Biology, 14, 193-205 
At low LIT,

Hardwood sites : $\%$ SOCloss $=-0.02 \mathrm{MAT}+0.71$

$$
\left(R^{2}=0.47 ; P<0.01 ; n=15\right) \text {. }
$$

Pine sites : \% SOC loss $=-0.02 \mathrm{MAT}+0.50$

$$
\left(R^{2}=0.68 ; P<0.01 ; n=11\right) \text {. }
$$

At high LIT,

Hardwood sites : \% SOCloss $=-0.04 \mathrm{MAT}+1.68$

$$
\left(R^{2}=0.21 ; P=0.08 ; n=15\right) \text {. }
$$

Pine sites : \% SOCloss $=-0.06 \mathrm{MAT}+1.49$

$$
\left(R^{2}=0.65 ; P<0.01 ; n=11\right) \text {. }
$$

\section{Discussion}

In this study, we tested the hypothesis that MAT negatively influences SOC quality. Our second hypothesis was that SOC quality is higher in soils formed under pine than hardwood-dominated stands. Our analyses of SOC decomposition rates over our 80-day incubations showed a decrease in SOC quality with increasing MAT, with no strong effect of forest type despite higher SOC content under hardwood than pine stands.

\section{Soil chemical and physical properties}

Previous work has shown higher SOC stabilization in the presence of expandable, high surface area and high CEC clay minerals such as chlorite or highly expandable smectite (Torn et al., 1997; Eusterhues et al., 2003; Wattel-Koekkoek \& Buurman, 2004; Rasmussen et al., 2006). For example, Wattel-Koekkoek et al. (2001) observed that soils rich in smectite, a 2:1 clay mineral with high $\mathrm{CEC}$, can hold more aromatic $\mathrm{C}$ compounds than soils rich in kaolinite, a 1:1 clay mineral characterized by low CEC. Among the expandable interlayered mineral phases, the different development of hydroxy$\mathrm{Al}$ interlayer explains the range of CEC and swelling potential across the range of high- and low-expandable smectite. In highly expandable smectite, the presence of charge in tetrahedral sites allows greater expansion and higher affinity for adsorption of organic molecules than in low-expandable smectite (Dontsova \& Bigham, 2005).

In line with previous studies (Birkeland, 1999), we observed decreasing presence of chlorite and highly expandable smectite with increasing MAT (Fig. 3). At warm sites, clays were composed mainly of lowexpandable smectite and kaolinite. As would be predicted from the change in soil clay mineralogy, where clays with a high capacity to fix $C$ at low MAT were replaced by clays with a much lower capacity to fix $C$ at warm sites, we observed that SOC content decreased with increasing MAT.

Total clay content may also influence SOC content, which tends to be greater in fine-textured soils because of the adsorption of organic molecules onto clay surfaces and aggregate formation (Oades, 1988; Jastrow \& Miller, 1997; Six et al., 2001). Studies of SOC pools also have shown that stable SOC is often associated with clay minerals (Torn et al., 1997; Eusterhues et al., 2003), and clay content is sometimes used to model SOC content (Schimel et al., 1985, 1994; Parton et al., 1987). However, we did not observe a relationship between clay content and SOC content across our sites. This finding may be a result of a limited range of clay content or the coarse-textured nature of our soils.

Total SOC also depends on $C$ inputs to soil and the effects of MAT on soil $C$ decomposition rates. The finding of decreasing SOC content with increasing MAT agrees with Raich et al. (2006), who hypothesized that reduced $C$ storage at high MAT derives from elevated NPP that is more than offset by enhanced decomposition. Our soil chemical data also point to warm climate soils having a lower capacity to stabilize SOC. Reduced SOC content at high MAT sites coincided with clay minerals and soil chemistry that reduce soil capacity to stabilize organic $\mathrm{C}$.

Soil $\mathrm{pH}$ declined by $\sim 1.8 \mathrm{pH}$ units while soil CEC also declined by half across our MAT gradient. Variation in $\mathrm{pH}$ can reduce the surface charge of minerals, while bivalent cations, especially calcium, can enhance C stabilization through cation bridging (Oades, 1988). Therefore, the combination of lower $\mathrm{pH}$ and CEC at high MAT sites may have further reduced the capacity of warm climate soils to stabilize SOC. These changes in mineralogy, $\mathrm{pH}$ and CEC across the MAT gradient likely relate to MAT effects on the weathering process. In agreement with these findings, we observed a positive relationship between soil $\mathrm{pH}$ and SOC content $\left(R^{2}=0.25 ; P<0.01 ; n=26\right)$. Therefore, the negative effect of MAT on SOC content may be indirect and result from the direct effects of MAT on soil mineralogy, CEC, and $\mathrm{pH}$.

\section{SOC decomposition rates}

Consistent with studies of forested (Winkler et al., 1996) and agricultural (Collins et al., 2000) soils, we found a rapid decrease in $\mathrm{SOC}$ decomposition rates during the initial phase of incubation. This pattern may be caused by the rapid utilization and consequent depletion of labile SOC due to the activity of soil microorganisms (Townsend et al., 1997; Paul et al., 2001). Alternatively, this pattern may reflect the depletion of $C$ made available during sampling and processing disturbance. The 
SOC decomposition rates observed in this study agree with those previously reported in the literature. Rates for our Colorado soils are consistent with 80 day results reported by Giardina et al. (2001) for soils sampled from Colorado aspen ( $35 \mathrm{mg} \mathrm{Cg}^{-1}$ soil C) and pine stands $\left(85 \mathrm{mg} \mathrm{Cg}^{-1}\right.$ soil C). On the warm end of our MAT gradient, SOC decomposition rates were slightly lower than those reported by Winkler et al. (1996) for heavily weathered South Carolina soils (approximately 20$30 \mathrm{mg} \mathrm{C} \mathrm{g}^{-1}$ soil $\left(120\right.$ day $^{-1}$ ). Overall, our rates fall within the range of rates reviewed by Giardina \& Ryan (2000).

\section{SOC quality and MAT}

In agreement with our first hypothesis (Fig. 1), decomposition rates for SOC in our 80-day experiment were negatively related to MAT. Given the observed changes in clay mineralogy, $\mathrm{CEC}$ and $\mathrm{pH}$, we interpret the decline in SOC quality with increasing MAT as having resulted primarily from two factors. First, stabilization reactions proceed more quickly at high temperatures (Dalias et al., 2001; Thornley \& Cannell, 2001), resulting in a larger proportion of total SOC occurring in stabilized, chemically protected forms. Second, NPP and litter decomposition rates increase positively with MAT, leading to lower quality detrital inputs to soil and lower biochemical quality of SOC.

For the $30^{\circ} \mathrm{C}$ incubations, a stepwise multiple linear regression explaining $36 \%$ of the variation in decomposition rates revealed that MAT $(P<0.01)$ and CEC $(P=0.04)$ were negatively related to decomposition rates. No other variables were significant. For the $10^{\circ} \mathrm{C}$ incubations, a stepwise multiple linear regression explaining $59 \%$ of the variation in decomposition rates revealed that $\mathrm{MAT}, \mathrm{CEC}$ and $\mathrm{pH}$ were all significant predictors of decomposition rate $-\operatorname{MAT}(P=0.02)$ and CEC $(P<0.01)$ were negatively related while $\mathrm{pH}$ $(P=0.02)$ was positively related to decomposition rate. This positive relationship between decomposition and $\mathrm{pH}$ has been observed previously for tropical soils (Motavalli et al., 1995). That SOC decomposition rates also were related negatively to CEC is in line with expected effects of increased bivalent cation supply on SOC stabilization (Oades, 1988). Because CEC and pH declined with MAT, the negative effect of MAT on SOC quality appears to have more than offset any opposing effects of declining $\mathrm{CEC}$ or $\mathrm{pH}$ on SOC quality.

More rapid stabilization of detrital $\mathrm{C}$ at warmer sites due to higher temperatures may be augmented by higher $\mathrm{N}$ availability, as SOC decomposition rates may be influenced by reactions between soil $\mathrm{N}$ and $\mathrm{C}$ compounds. Soil $\mathrm{C}: \mathrm{N}$ may serve as an index of these reactions, and as many terrestrial ecosystems are $\mathrm{N}$ - limited (Vitousek \& Howarth, 1991), C:N may also influence microbial decomposition and SOC quality. For surface litter, high $\mathrm{C}: \mathrm{N}$ typically is associated with low decomposition rates (Melillo et al., 1982; Norby et al., 2001). However, over longer time steps, Berg (2000) suggested that litter with low $C: N$ may lead to higher SOC stabilization, even though initially high $\mathrm{N}$ content in litter may enhance short-term decomposition rates. In our study, $\mathrm{C}: \mathrm{N}$ of $\mathrm{SOC}$ was higher and total $\mathrm{C}$ content lower for pine than hardwood stands while SOC decomposition rates were similar between forest types, in line with the findings of Giardina et al. (2001) who found that $C: N$ of soils was a poor predictor of soil $C$ decomposition rates. Overall, soil $C: N$ was unrelated to both MAT and soil $C$ decomposition rates at 10 or $30^{\circ} \mathrm{C}(P=0.19$ and $P=0.14$, respectively), and was excluded in a stepwise multiple linear regression, indicating that while an important predictor of initial leaf litter decomposition rates, $\mathrm{C}: \mathrm{N}$ may be a weak predictor of SOC decomposition.

In our study, variation in SOC quality cannot be easily explained by variation in clay mineralogy (Wattel-Koekkoek et al., 2001; Rasmussen et al., 2006). Across our sites, low SOC decomposition rates occurred at sites with high MAT where clay minerals have a lower affinity for SOC. Similarly, at cold sites, SOC decomposition rates were highest despite the presence of clay minerals that have higher affinity for SOC.

Temperature sensitivity $\left(Q_{10}\right)$ of SOC decomposition across SOC quality (labile to more stable SOC) can be quantified by estimating $Q_{10}$ of decomposition at different points in our incubation. We found that temperature sensitivity at different days of incubation and SOC decomposition rates were positively related at high LIT, indicating that substrate availability can affect the temperature responsiveness of SOC decomposition - in agreement with evidence presented by Giardina \& Ryan (2000) and a recent global-scale modeling study (Ise \& Moorcroft, 2006). In contrast to high-LIT, at low-LIT substrate is more slowly depleted resulting in smaller relative declines in SOC decomposition rates during the incubation.

Overall, an improved understanding of the mechanisms driving the decline in SOC content with MAT is needed if the effects of global warming on the soil $\mathrm{C}$ reservoir, and the time steps of loss, are to be accurately modeled. If reduced SOC content is the direct result of MAT effects on SOC decomposition rate, than warming could have a rapid influence on SOC storage. If, however, SOC content is regulated primarily by soil mineralogy and chemistry, it is possible that warming will not influence SOC content in the absence of longer-term changes in soil mineralogy, $\mathrm{CEC}$ and $\mathrm{pH}$. Because SOC quality actually declined with increasing MAT, we 
suggest that declining SOC content results from the direct effects of MAT on soil chemical properties.

\section{SOC and forest type}

Forest types differ in the quality of detritus returned to soils, with important consequences for biogeochemistry and ecosystem function (Binkley \& Giardina, 1998). A previous study reported that high quality litter can result in low quality SOC (Giardina et al., 2001). Based on these findings and the observation that in the longterm, high $\mathrm{N}$ content litter can negatively affect decomposer communities (Berg \& Meentemeyer, 2002), we investigated whether SOC quality is higher under pine than hardwood across an extended range of MAT.

In contrast to Giardina et al. (2001), who during a 16month incubation experiment observed \%SOC loss to be higher in pine than hardwood soils, \%SOC loss in this study did not differ between forest types, despite higher $\mathrm{C}: \mathrm{N}$ in pine soils and higher SOC content in hardwood soils, as was found by Giardina et al. (2001) for aspen and pine forests in Colorado. Van Miegroet et al. (2005) found similar \%SOC loss for conifer and aspen soils in Utah, in agreement with evidence that litter quality and SOC quality may not be correlated (Melillo et al., 1989). Differences with Giardina et al. (2001) may relate to the low and narrow range of soil textures examined in our study. In addition, unidentified but important factors may control SOC quantity and quality across forest types and further analysis is needed to explain these relationships.

Our findings suggest that possible changes in vegetation (e.g. from pine to hardwood at cool sites or from hardwood to pine at warm sites) due to climate change or management may impact SOC content but not SOC quality. However, we caution that small differences in clay content between forest types in part may explain differences in SOC content. Clearly, new experiments are needed to better understand the temperature responses of labile and stable SOC in relation to forest type.

\section{Conclusions}

A positive correlation between SOC quality and MAT would lead to the prediction that warming-induced changes in SOC quality will feedback positively on decomposition rates, atmospheric $\mathrm{CO}_{2}$ concentration and hence global warming. In contrast, if SOC quality is negatively correlated with MAT, any feedbacks would be reduced as relatively more SOC would occur in stabilized forms at high MAT. Our study showed that SOC quality and quantity both declined with increasing MAT. These findings indicate that the total amount of $C$ in soil will decrease with global warming despite increased stability of that SOC. Because soil capacity to stabilize SOC declined with MAT due in part to changes in soil chemistry and mineralogy, the effects of climate change on SOC content and quality may be difficult to model under scenarios of global warming without a more explicit consideration of soil chemical and mineralogical effects. While SOC content declined with MAT, the effects of mineralogy and CEC on SOC decomposition rates showed that soil effects on SOC quality can be offset by opposing climate effects on SOC quality.

Despite greater SOC content in hardwood than pine stands, our short-term incubation experiment did not detect differences in SOC quality between hardwood and pine stands along the gradient in MAT. Long-term lab and in situ experiments may be necessary to identify an effect of forest type on SOC quality. Taken together our study indicates that global warming may decrease SOC quality and quantity across biomes, whereas changes in vegetation may alter SOC content but not SOC quality.

\section{Acknowledgements}

We thank Noah Karberg and Erik Lilleskov for valuable assistance and insights into soil C cycling, Jennifer Eikenberry for assistance with Gas Chromatography, and the Northern, Southern and Pacific Southwest Research Stations of the USDA Forest Service for funding and support of this research. Finally, we thank MeadWestvaco Inc., for access to field sites in Michigan, and the comments of anonymous reviewers that greatly improved this manuscript.

\section{References}

Ågren GI, Bosatta E (1996) Quality: a bridge between theory and experiment in soil organic matter studies. Oikos, 76, 522-528.

Bachelet D, Neilson RP, Lenihan JM, Drapek RJ (2001) Climate change effects on vegetation distribution and carbon budget in the United States. Ecosystems, 4, 164-185.

Balesdent J, Mariotti A, Boisgontier D (1990) Effect of tillage on soil organic carbon mineralization estimated from ${ }^{13} \mathrm{C}$ abundance in maize fields. Journal of Soil Science, 41, 587-596.

Barnhisel RI, Bertsch PM (1989) Chlorites and hydroxy-interlayered vermiculite and smectite. In: Minerals in Soil Environments (eds Dixon JB, Weed SB), pp. 729-788. Soil Science Society of America, Madison, WI.

Berg B (1986) Nutrient release from litter and humus in coniferous for estimating soil carbon pools in tropical forest soils - a mini review. Scandinavian Journal of Forest Research, 1, 359-369.

Berg B (2000) Litter decomposition and organic matter turnover in northern forest soils. Forest Ecology and Management, 133, 13-22.

Berg B, Matzner E (1997) Effect of N deposition on decomposition of plant litter and soil organic matter in forest ecosystems. Environmental Review, 5, 1-25. 
Berg B, Meentemeyer V (2002) Litter quality in a north European transect versus carbon storage potential. Plant and Soil, 242, 83-92.

Binkley D, Giardina CP (1998) Why do trees species affect soils? The warp and woof of tree-soil interactions. Biogeochemistry, 42, 89-106.

Birkeland PW (1999) Soils and Geomorphology, 3rd edn. Oxford University Press, New York.

Carter MR (1993) Soil Sampling and Methods of Analysis. Canadian Society of Soil Science, Lewis Publishers, Boca Raton, FL.

Collins HP, Elliott ET, Paustian K et al. (2000) Soil carbon pools and fluxes in long-term corn belt agroecosystems. Soil Biology and Biochemistry, 32, 157-168.

Dalias P, Anderson JM, Bottner P, Coûteaux MM (2001) Temperature responses of carbon mineralization in conifer forest soils from different regional climates incubated under standard laboratory conditions. Global Change Biology, 6, 181-192.

Dontsova KM, Bigham JM (2005) Anionic polysaccharide sorption by clay minerals. Soil Science Society of America Journal, 69, 1026-1035.

Douglas LA (1989) Vermiculites. In: Minerals in Soil Environments, 2nd edn (eds Dixon JB, Weed SB), pp. 635-668. Soil Science Society of America, Madison, WI.

Eusterhues K, Rumpel C, Kleber M, Kögel-Knabner I (2003) Stabilization of soil organic matter by interactions with minerals as revealed by mineral dissolution and oxidative degradation. Organic Geochemistry, 34, 1591-1600.

Gaudinski JB, Trumbore SE, Davidson EA, Zheng S (2000) Soil carbon cycling in a temperate forest: radiocarbon-based estimates of residence times, sequestration rates and partitioning of fluxes. Biogeochemistry, 51, 33-69.

Gee GW, Bauder JW (1986) Particle-size analysis. In: Methods of Soil Analysis. Part 1, Physical and Mineralogical Methods (ed. Page AL), pp. 383-411. Agronomy Monograph, American Society of agronomy, Madison, WI.

Giardina CP, Coleman MD, Hancock JE et al. (2005) The response of belowground carbon allocation in forests to global change. In: Tree Species Effects on Soils: Implications for Global Change. NATO Science Series, Vol. 55 (eds Binkley D, Menyailo O), pp. 119-154. Kluwer Academic Publishers, Dordrecht.

Giardina CP, Ryan MG (2000) Evidence that decomposition rates of organic carbon in mineral soil do not vary with temperature. Nature, 404, 858-861.

Giardina CP, Ryan MG, Hubbard RM, Binkley D (2001) Tree species and soil texture controls on carbon and nitrogen mineralization rates. Soil Science Society of America Journal, 65, 1272-1279.

Gower ST, Gohlz HL, Kaneyuki N, Baldwin VC (1994) Production and carbon allocation patterns of pine forests. Ecological Bulletins, 43, 115-135.

Guo LB, Gifford RM (2002) Soil carbon stock and land use change: a meta analysis. Global Change Biology, 8, 345-360.

Ise T, Moorcroft PR (2006) the global-scale temperature and moisture dependencies of soil organic carbon decomposition: an analysis using a mechanistic decomposition model. Biogeochemistry, 80, 217-231.
Jastrow JD, Miller RM (1997) Soil aggregate stabilization and carbon sequestration: feedbacks through organo-mineral association. In: Soil Processes and the Carbon Cycle (eds Lal R, Kimble JM, Follet RF, Stewart BA), pp. 207-230. CRC Press, New York. Joffre R, Ågren GI (2001) From plant to soil: litter production and decomposition. In: Terrestrial Global Productivity (eds Roy J, Saugier B, Mooney HA), pp. 83-99. Academic Press, New York.

Kahle M, Kleber M, Jahn R (2002) Review of XRD-based quantitative analyses of clay minerals in soils: the suitability of mineral intensity factors. Geoderma, 109, 191-205.

McBride MB (1994) Environmental Chemistry of Soils. Oxford University Press, New York, USA.

Meentenmeyer V (1982) World patterns and amounts of terrestrial plant litter production. BioScience, 32, 125-128.

Melillo JM, Aber JD, Linkins AE, Ricca A, Fry B, Nadelhoffer KJ (1989) Carbon and nitrogen dynamics along the decay continuum: plant litter to soil organic matter. Plant Soil, 115, 189198.

Melillo JM, Aber JD, Muratore JM (1982) Nitrogen and lignin control of hardwood leaf litter decomposition dynamics. Ecology, 63, 621-626.

Moore MD, Reynolds RC (1989) X-Ray Diffraction and the Identification and Analysis of Clay Minerals. Oxford University Press, Oxford.

Motavalli PP, Palm CA, Parton WJ, Elliot ET, Frey SD (1995) Soil $\mathrm{pH}$ and organic $\mathrm{C}$ dynamics in tropical forest soils: evidence from laboratory and simulation studies. Soil Biology and Biochemistry, 27, 1589-1599.

Norby RJ, Cotrufo MF, Ineson P, O'Neill EG, Canadell JG (2001) Elevated $\mathrm{CO}_{2}$, litter chemistry, and decomposition: a synthesis. Oecologia, 127, 153-165.

Oades JM (1988) The retention of organic matter in soils. Biogeochemistry, 5, 35-70.

Ottner F, Gier S, Kuderna M, Schwaighofer B (2000) Results of an inter-laboratory comparison of methods for quantitative clay analysis. Applied Clay Science, 17, 223-243.

Parton WJ, Schimel DS, Cole CV, Ojima DS (1987) Analysis of factors controlling soil organic matter levels in Great Plains grasslands. Soil Science Society of America Journal, 51, 1173-1179.

Paul EA, Clark FE (1996) Soil Microbiology and Biochemistry, 2nd edn. Academic Press, San Diego, CA.

Paul EA, Morris SJ, Böhm S (2001) The determination of soil C pool sizes and turnover rates: biophysical fractionation and tracers. In: Assessment Methods for Soil Carbon (eds Lal R et al.), pp. 193-205. Lewis Publications, Boca Raton, FL.

Paul EA, Morris SJ, Conant RT, Plante AF (2006) Does the acidhydrolysis incubation method measure meaningful soil organic carbon pools? Soil Science Society of America Journal, 70, 10231035.

Prescott CE, Zabek LM, Staley CL, Kabzems R (2000) Decomposition of broadleaf and needle litter in forests of British Columbia: influences of litter type, forest type and litter mixtures. Canadian Journal of Forests Research, 30, 1742-1750.

Raich JW, Russel AE, Kitayama K, Parton WJ, Vitousek PM (2006) Temperature influences carbon accumulation in moist tropical forests. Ecology, 87, 76-87. 
Rasmussen C, Southard RJ, Horwath WR (2006) Mineral control of organic carbon mineralization in a range of temperate conifer forest soils. Global Change Biology, 12, 834-847.

Rovira P, Vallejo VR (2002) Labile and recalcitrant pools of carbon and nitrogen in organic matter decomposition at different depths in soil: an acid hydrolysis approach. Geoderma, 107, 109-141.

Russell AE, Raich JW, Valverde-Barrantes OJ, Fisher RF (2007) Tree species effects on soil properties in experimental plantations in tropical moist forest. Soil Science Society of America Journal, 71, 1389-1397.

Sanchez PA (1976) Properties and Management of Soils in the Tropics. Wiley Interscience, New York.

Schimel DS, Coleman DC, Horton KA (1985) Soil organic matter dynamics in paired rangeland and cropland toposequences in north Dakota. Geoderma, 36, 201-214.

Schimel DS, Holland EA, McKeown R (1994) Climatic, edaphic, and biotic controls over storage and turnover of carbon in soils. Global Biogeochemical Cycles, 8, 279-294.

Scott NA, Binkley D (1997) Foliage litter quality and annual net $\mathrm{N}$ mineralization: comparison across North American forest sites. Oecologia, 111, 151-159.

Shang C, Tiessen H (2000) Carbon turnover and carbon-13 natural abundance in organo-mineral fractions of a tropical dry forest soil under cultivation. Soil Science Society of America Journal, 64, 2149-2155.

Shaver GR, Canadell J, Chapin FS et al. (2000) Global warming and terrestrial ecosystems: a conceptual framework for analysis. Bioscience, 50, 871-882.

Six J, Carpentier A, van Kessel C, Merckx R, Harris D, Horwath WR, Lüscher A (2001) Impact of elevated $\mathrm{CO}_{2}$ on soil organic matter dynamics as related to changes in aggregate turnover and residue quality. Plant and Soil, 234, 27-36.

Six J, Conant RT, Paul EA, Paustian K (2002) Stabilization mechanisms of soil organic matter: implications for C-saturation of soils. Plant and Soil, 241, 155-176.

Smolander A, Loponene J, Suominen K, Kitunen V (2005) Organic matter characteristics and $\mathrm{C}$ and $\mathrm{N}$ transformations in the humus layer under two tree species, Betula pendula and Picea abies. Soil Biology and Biochemistry, 37, 1309-1318.

Srebotnik E, Jensen KA, Hammel KE (1994) Fungal degradation of recalcitrant nonphenolic lignin structures without lignin peroxidase. Proceedings of the National Academy of Sciences of the United States of America, 91, 12794-12797.

Stevenson FJ (1994) Humus Chemistry: Genesis, Composition, Reactions, 2nd edn. John Wiley \& Sons Inc., New York.

Thornley JHM, Cannell MGR (2001) Soil carbon storage responses to temperature: an hypothesis. Annals of Botany, 87, 591-598.

Thorez J (1976) Practical identification of clay minerals. In: A Handbook for Teachers and Students in Clay Mineralogy (ed. Lelotte G), Dison, Belgium.

Torn MS, Trumbore SE, Chadwick OA, Vitousek PM, Hendricks DM (1997) Mineral control of soil organic carbon storage and turnover. Nature, 389, 170-173.

Townsend AR, Vitousek PM, Desmarais DJ, Tharpe A (1997) Soil carbon pool structure and temperature sensitivity inferred using $\mathrm{CO}_{2}$ and ${ }^{13} \mathrm{CO}_{2}$ incubation fluxes from five Hawaiian soils. Biogeochemistry, 38, 1-17.

Trumbore SE (1997) Potential responses of soil organic carbon to global environmental change. Proceedings of the National Academy of Science USA, 94, 8284-8291.

Van Miegroet H, Boettinger JL, Baker MA, Nielsen J, Evans D, Stum A (2005) Soil carbon distribution and quality in a montane rangeland-forest mosaic in northern Utah. Forest Ecology and Management, 220, 284-299.

Vitousek PM, Howarth RW (1991) Nitrogen limitation on land and in the sea: how can it occur? Biogeochemistry, 13, 87-115.

Waldrop MP, Firestone MK (2004) Microbial community utilization of recalcitrant and simple carbon compounds: impact of oak-woodland plant communities. Oecologia, 138, 275-284.

Walther G-R, Post E, Convey P et al. (2002) Ecological responses to recent climate change. Nature, 416, 389-395.

Wattel-Koekkoek EJW, Buurman P (2004) Mean residence time of kaolinite and smectite-bound organic matter in Mozambiquan Soils. Soil Science Society of America Journal, 68, 154-161.

Wattel-Koekkoek EJW, Buurman P, Van der Plicht J, Wattel E, Vallaeys T, van Breemen N (2001) Amount and composition of clay-associated soil organic matter in a range of kaolinitic and smectitic soils. Geoderma, 99, 27-49.

Winkler JP, Cherry RS, Schlesinger WH (1996) The $Q_{10}$ relationship of microbial respiration in a temperate forest soil. Soil Biology and Biochemistry, 28, 1067-1072. 
